\title{
Comparative Study of floating column of multi storey building by using software
}

\author{
Ms.Waykule .S.B ${ }^{1}$, Dr.C.P.Pise ${ }^{2}$, Mr. C.M. Deshmukh ${ }^{3}$, Mr.Y .P . Pawar ${ }^{3}$, \\ Mr S .S Kadam ,Mr.D .D .Mohite, Ms.S.V. Lale ${ }^{3}$. \\ ${ }^{1} P G$ Student, SKN Sinhgad College of Engineering, Korti, Pandharpur, Maharastra, India. \\ ${ }^{2}$ Associate Professor \& HOD, DepartmentCivil Engineering Department, SKN Sinhgad College of Engineering, \\ Korti, Pandharpur, Maharastra, India. \\ ${ }^{3}$ Assistant Professor, Department of Civil Engineering, SKN Sinhgad College of Engineering, Korti, \\ Pandharpur,
}

\section{ABSTRACT}

Floating columns are a typical feature in the modern multi-storey construction in urban India and are highly undesirable in buildings built in seis mically active areas. In this paper static analysis is done for a multi-storey building with and without floating columns. Different cases of the building are studied by varying the location of floating columns floor wise. The structural response of the building models with respect to, Base shear, and Storey displacements is investigated. The analys is is carried out using software sap2000v 17.

Keywords: Floating column, linear static analysis, sap2000v17.

\section{NTRODUCTION}

In recent times, multi-storey buildings in urban cities are required to have column free space due to shortage of space, population and also for aesthetic and functional requirements. For this buildings are provided with floating columns at one or more storey. These floating columns are highly disadvantageous in a building built in seismically active areas. The earthquake forces that are developed at different floor levels in a building need to be carried down along the height to the ground by the shortest path. Deviation or discontinuity in this load transfer path results in poor performance of the building. The behavior of a building during earthquakes depends critically on its overall shape, size and geometry, in addition to how the earthquake forces are carried to the ground. Many buildings with an open ground storey intended for parking collapsed or were severely damaged in Gujarat during the 2001 Bhuj earthquake.[1]

Floating Column: The floating column is a vertical member which rest on a beam and doesn't have a foundation. The floating column act as a point load on the beam and this beam transfers the load to the columns below it. [4]

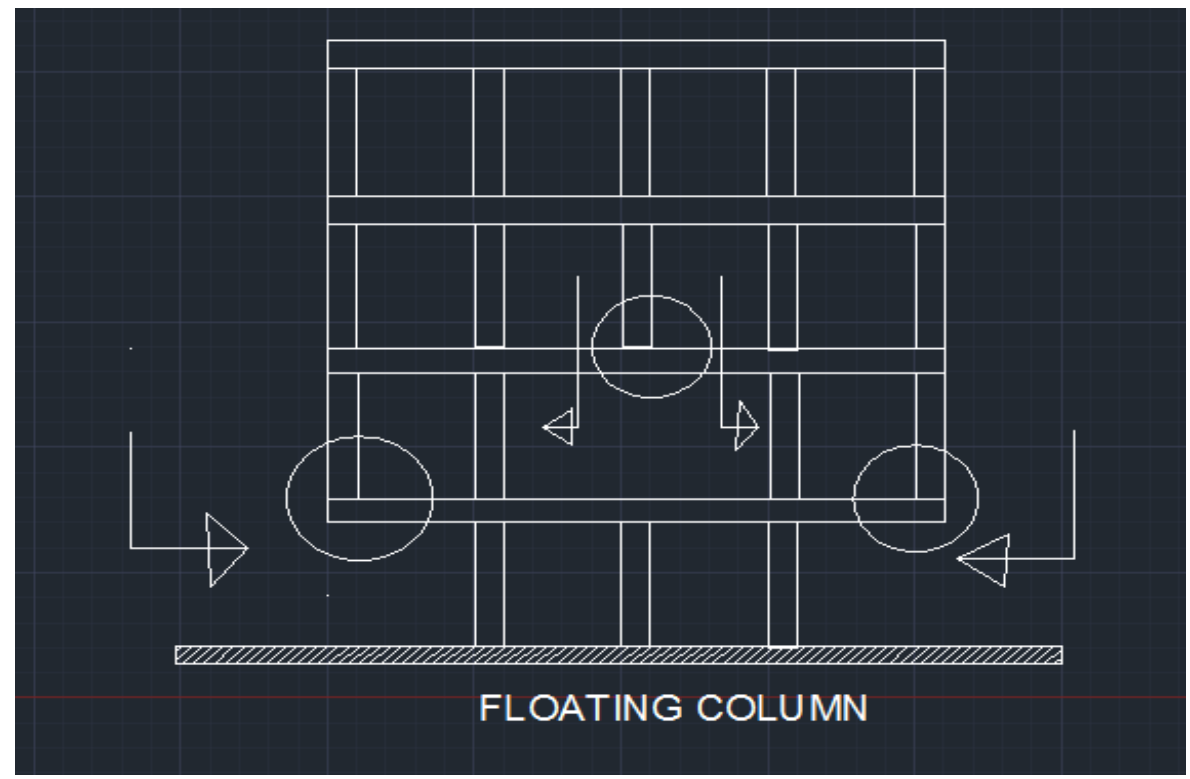

Fig no.1 Floating colu mn in building. 


\section{REVIEW PAPERS}

1.Sukumar Behera*In this paper involve stiffness balance of first storey and the storey above are studied to reduce irregularity occurs due to presence floating column. To study response of structures under different earthquake excitation having different frequency content keeping the PGA and time duration factor constant they develop FEM codes for 2D frames with and without floating column. The behavior of building frame with and without floating column is studied under static load, free vibration and forced vibration condition. The finite element code has been developed in MATLAB platform. The time history of floor displacement, inter storey drift, base shear, overturning moment are computed for both the frames with and without floating column. The dynamic analysis of frame is studied by varying the column dimension. It is concluded that with increase in ground floor column the maximum displacement, inter storey drift values are reducing. The base shear and overturning moment vary with the change in colu mn dimension.[1]

2. Shrikanth M.K* ${ }^{*}$,Yogendra.R.Holebagilu ${ }^{2}$ In this paper study is all about to compare the behavior of a building having only floating column and having floating column with complexities. High rise building is analyzed for earthquake force. for that purpose created four models and analyzed for lower and higher seismic zones for medium soil condition. analysis was carried out by using extended 3 dimensional analysis of building system ETAB version 9.7.4 software. results are presented in terms of Displacement, soft storey, storey drift for these four models and tabulated on basis of linear seismic analysis.[2]

3. T.raja sekhar*,Mr.P.V.Prasad ${ }^{1}$ The behavior of building frame with and without floating column is studied under static load, free vibration and forced vibration condition. The results are plotted for both the frames with and without floating column by comparing each other time history of floor displacement, base shear. The equivalent static analysis is carried out on the entire project mathematical 3D model using the software STAAD Pro V8i and the comparison of these models are been presented. This will help us to find the various analytical properties of the structure and we may also have a very systematic and economical design for the structure. [3]

4. A.p.mundada*,S.G.Sawadak arIn this paper study is done for architectural drawing and the framing drawing of the building having floating columns. For comparision $\mathrm{G}+7$ existing residential building with and without floating column are taken for carry out entire project work. by using STAAD Pro V8i 3D 3 model are created .equivalent static analysis of these model are done by using STAAD Pro V8i .Different parameters such as axial load , mo ment distribution, importance of line of action of force and seismic factors are studied for models. This will help them to find the various analytical properties of the structure and also have a very systematic and economical design for the structure.[4]

5. Hardik Bhensdadia*,Siddarth shah In this study an attempt is made to reveal the effects of floating colu mn \& soft story in different earthquake zones by seismic analysis. For this purpose Push over analysis is adopted because this analysis will yield performance level of building for design capacity (displacement) carried out up to failure, it helps determination of collapse load and ductility capacity of the structure. To achieve this objective, three RC bare frame structures with $\mathrm{G}+4, \mathrm{G}+9$, $\mathrm{G}+15$ stories respectively will be analysed and compared the base force and displacement of RC bare frame structure with $\mathrm{G}+4, \mathrm{G}+9, \mathrm{G}+15$ stories in diffe rent earthquake zones like Rajkot, Jamnagar and Bhuj using SAP 200014 analysis package.[5]

\section{METHODOLOGY}

The main objectives of the proposed work are:

1. Static linear analysis of different building having floating colu mn at different floors.

2. To compare the Base shear, Storey displacement.

\subsection{Gui delines For Using Sap2000v17}

Click on new for a new model, This asks us to select a new template and gives various options for the same as in the figure 1 given below. Select Grid only

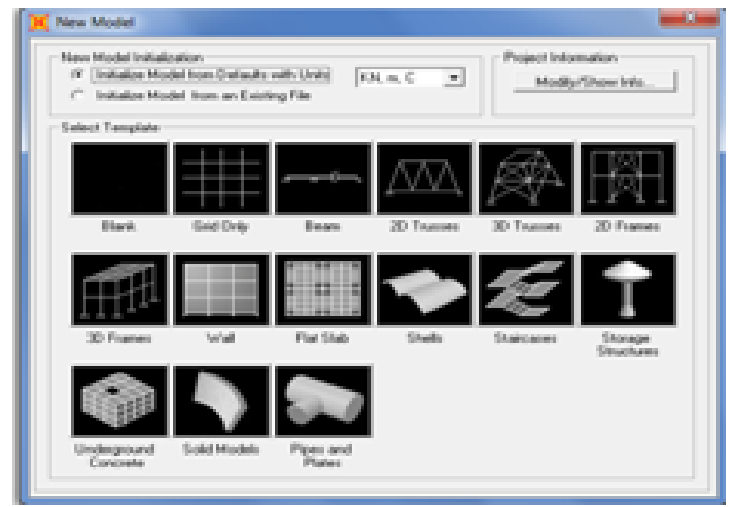

Fig no.2 New model form

After selecting Grid only, the following figure appears asking for the number of grid lines in every direction and also the grid spacing in all directions. As per your design, give the values for grid lines and click on OK. Remember: Grid lines are the lines passing through the center of columns 
in both the directions. $\mathrm{X}$ direction- horizontal grid lines in plan Y direction- vertical grid lines in plan $\mathrm{Z}$ direction- vertical grid lines in elevation. After having provided the values for grid lines, the software generates the model for the given values as shown in figure. The model is seen both in plan and 3D simu ltaneously.[14]

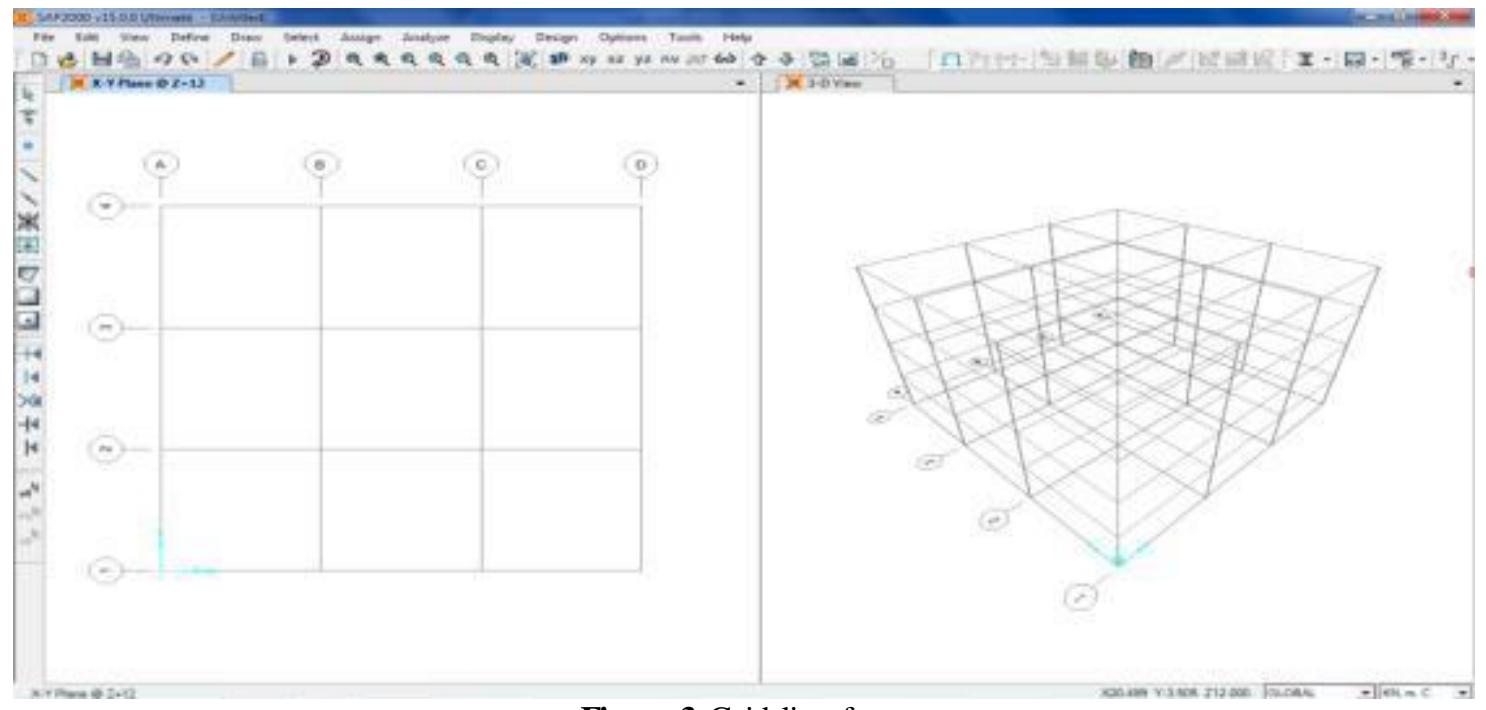

Fig no.3 Grid line form

\subsection{Defining material property:}

click on define, select section properties, select slab sections, click on add new property.[14]

\subsection{Appl ying load patterns for the model}

Type the name new load pattern ,EQX .Select QUAKE, a type load from the dropdown list. make sure that self weight multiplier set to zero, click add new load pattern button to add EQX load to the list. Repeat the same for EQY load.

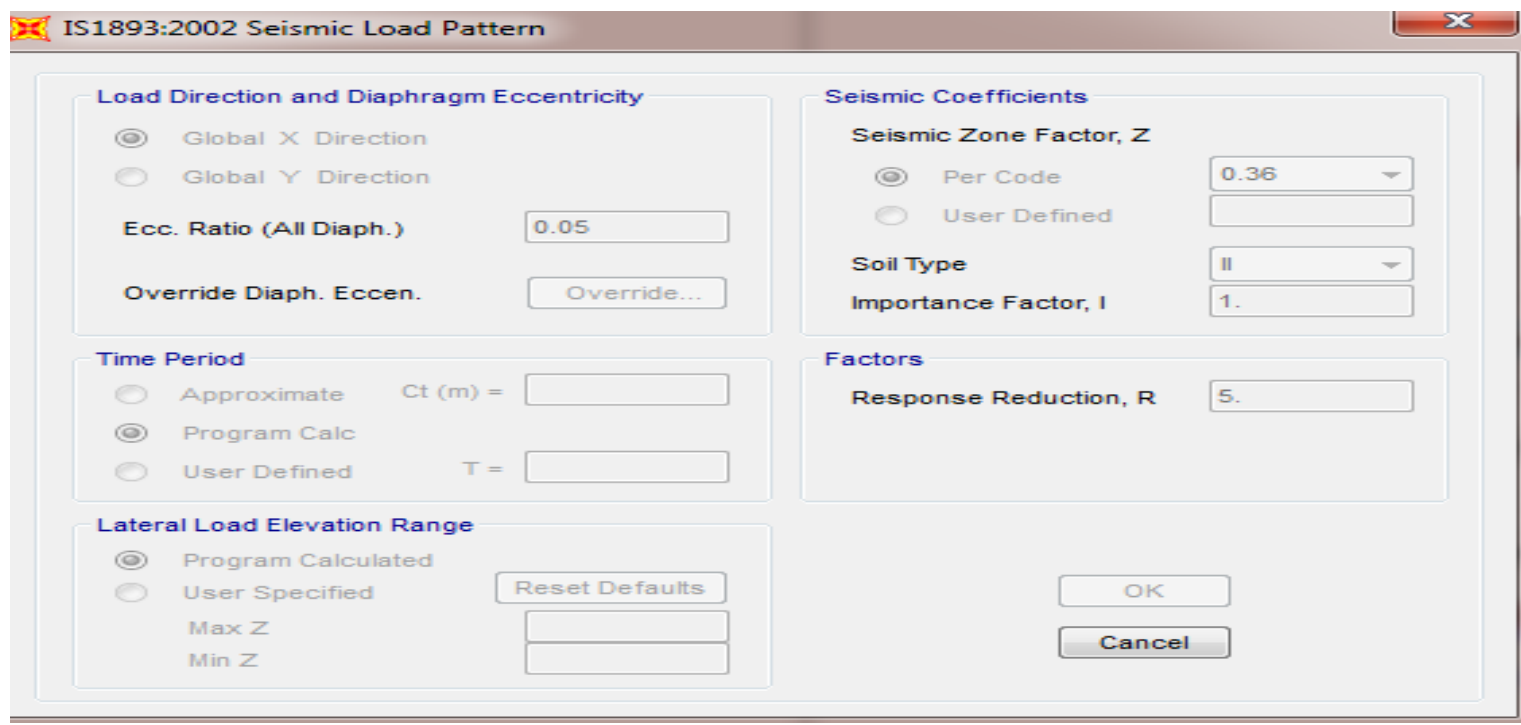

Fig no.4 Seis mic load pattern

repeat the process for various load patterns. give load patterns as dead, live, superimposed. note: for dead load, the self-weight multiplier is 1 . and for the rest all is considered as 0 . For superimposed load, the type is super dead. [14] 


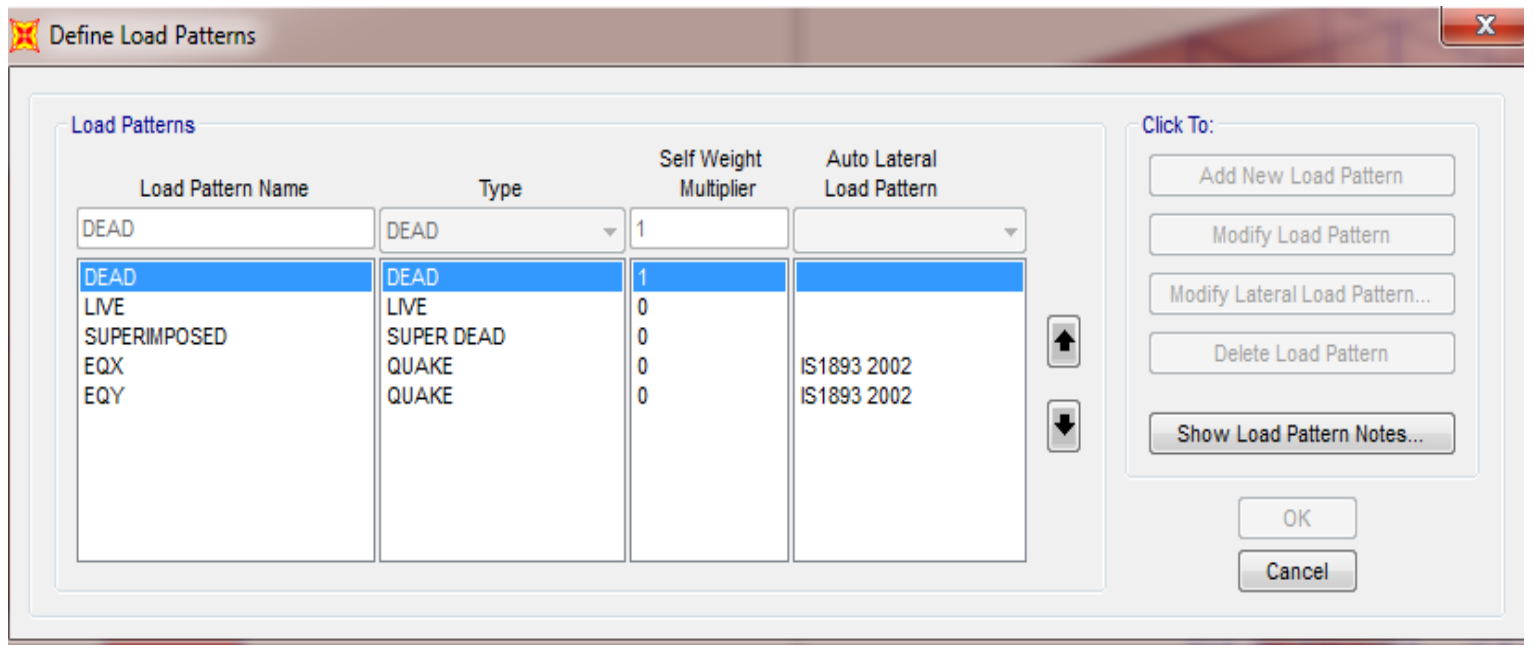

Fig no.5 Define load patterns form

\section{PROBLEM STATEMENT}

A five storied building with floating column at $1^{\text {st }}$ floor and building with floating column at $2^{\text {nd }}$ floor and building without floating column located in zone $\mathrm{v}$ of india as per code IS 1893(Part1):2002 were taken for the investigation. linear static analysis of buildings were done under gravity loads and seismic loads. Then compare base shear and storey displacement of each building. Modeling and analysis was carried out in sap 2000v17.modeling consists of following step: Building detail

1. Build ing dimensions: $16.70 \mathrm{~m} \times 7.55 \mathrm{~m}$
2. Height of floor: $3.1 \mathrm{~m}$

3. Column sizes: $230 \mathrm{~mm} \times 450 \mathrm{~mm}$, $230 \mathrm{~mm} \times 380 \mathrm{~mm}$.

4. Beam sizes: $230 \mathrm{~mm} \times 450 \mathrm{~mm}$.

5. Slab thic kness: $125 \mathrm{~mm}$.

6. Grade of concrete: M20

7. Grade of steel: Fe500

8. Density of masonry: $18 \mathrm{KN} / \mathrm{m}^{3}$

9. Density of concrete: $25 \mathrm{KN} / \mathrm{m}^{3}$

10. Se is mic zone: $\mathrm{V}$

11. Importance factor: 1

12. Build ing frame: Special RC moment resisting frame (SMRF)

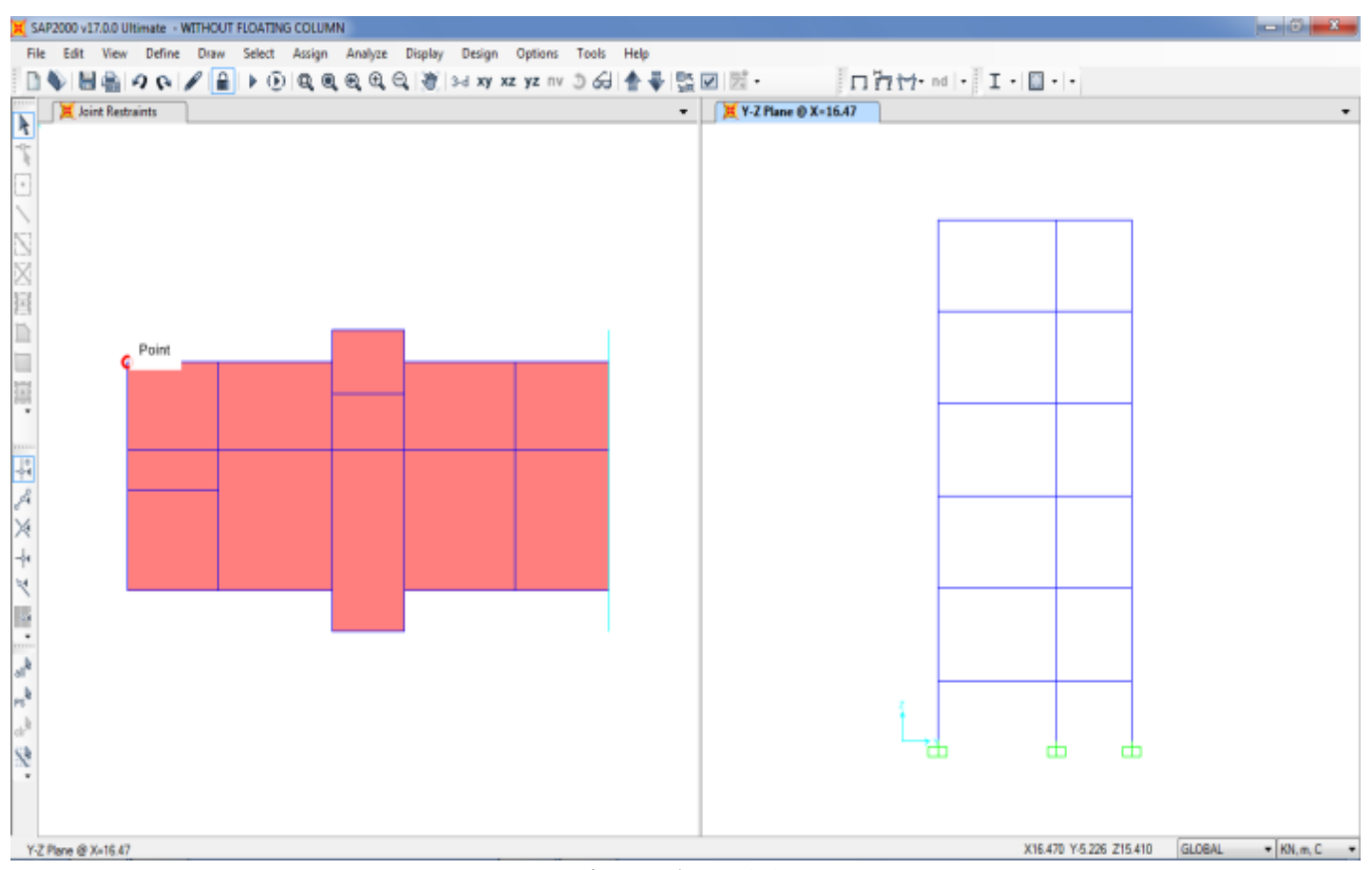

Fig no.6 Model 1 


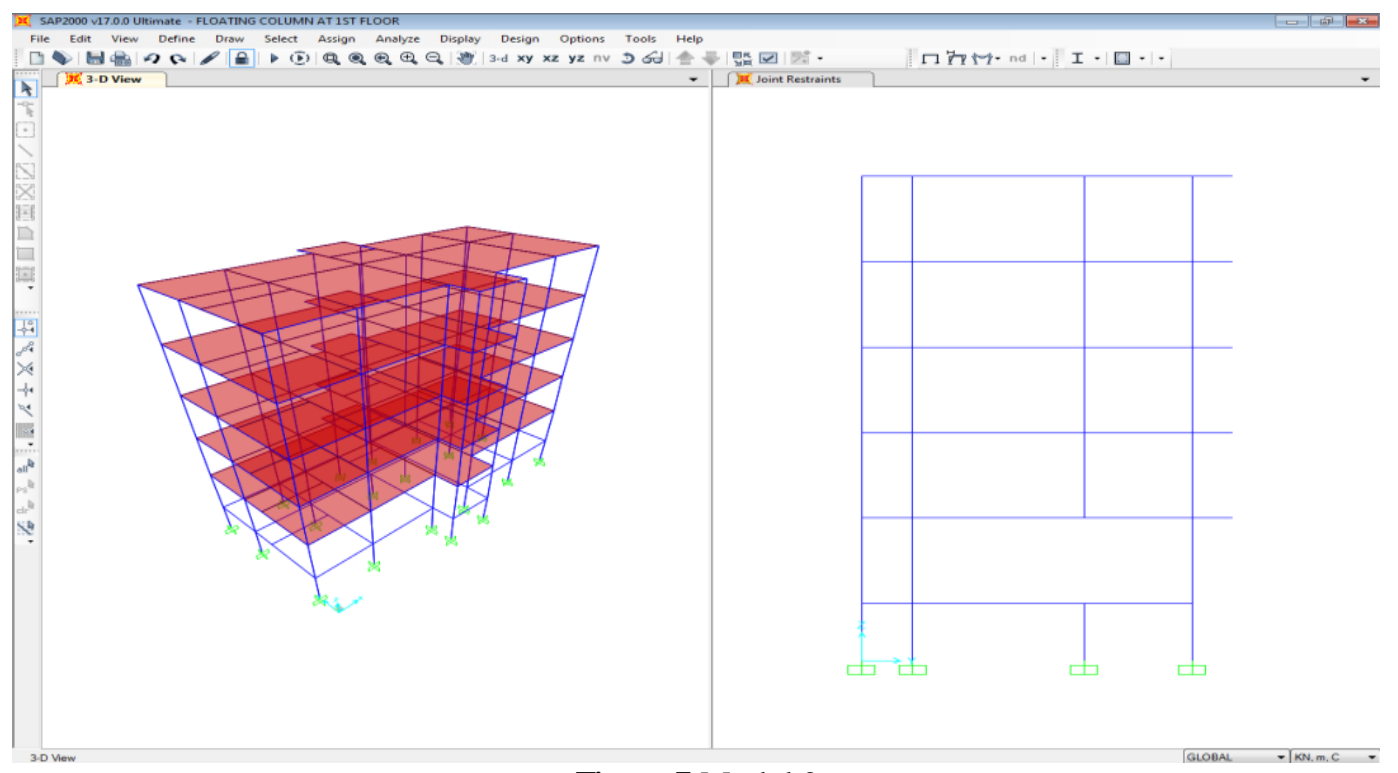

Fig no.7 Model 2

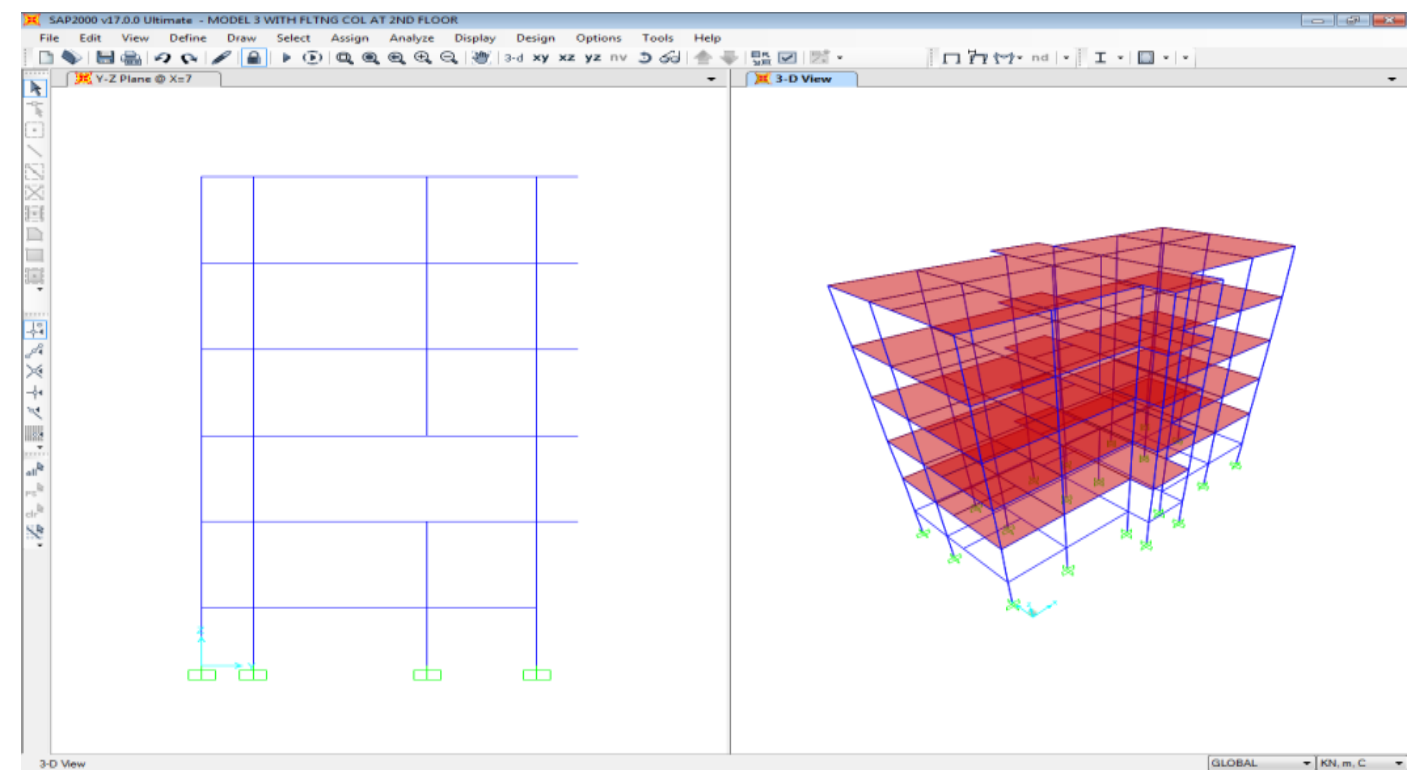

Fig no.8 Model 3

\section{RESULT}

In the present study, the effect of varying the location of floating columns floor wise of multi storey RC building on various structural response quantities of the building using static analysis. The results are compared in tabular form and graphically for the analysis of the building without floating columns and with floating columns.

\section{A. B ase shear}

Base shear is the horizontal reaction at the base against horizontal earthquake load. Th is base shear is acting at the base or supports of the structure or wherever structure is fixed.

Table no.1 Base shear in $\mathrm{x}$ direction

\begin{tabular}{|l|l|}
\hline Model & Base shear in $\mathrm{x}$ direction in KN \\
\hline WITHOUT F/C & 379.336 \\
\hline F/C AT $1^{\text {ST }}$ FLOOR & 371.176 \\
\hline F/C AT 2 ${ }^{\text {ND }}$ FLOOR & 372.597 \\
\hline
\end{tabular}




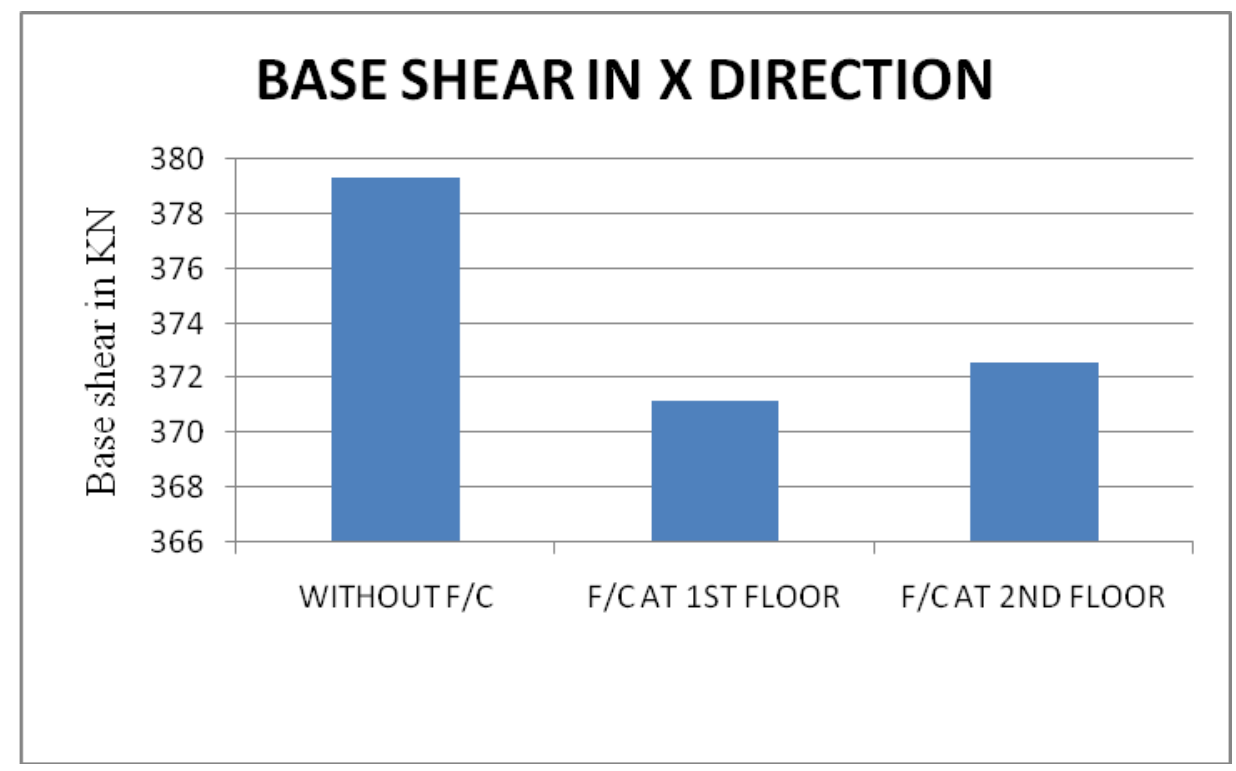

Fig no.9 Base shear in $\mathrm{KN}$

\section{B. Storey Displacement.}

Storey displacement is the lateral movement of the structure caused by lateral force.

Table no.2 Storey displacement

\begin{tabular}{|l|l|l|l|}
\hline HEIGHT & \multicolumn{3}{|l|}{ DISPLACEMENT } \\
\hline & Model 1 & Model 2 & Model 3 \\
\hline 17 & 0 & 0 & 0 \\
\hline 14 & 0.00082 & 0.000904 & 0.000845 \\
\hline 11 & 0.003526 & 0.003844 & 0.003572 \\
\hline 8 & 0.006583 & 0.006606 & 0.006365 \\
\hline 5 & 0.009119 & 0.009113 & 0.008919 \\
\hline 2 & 0.011143 & 0.011128 & 0.010972 \\
\hline 0 & 0.012409 & 0.012388 & 0.012254 \\
\hline
\end{tabular}

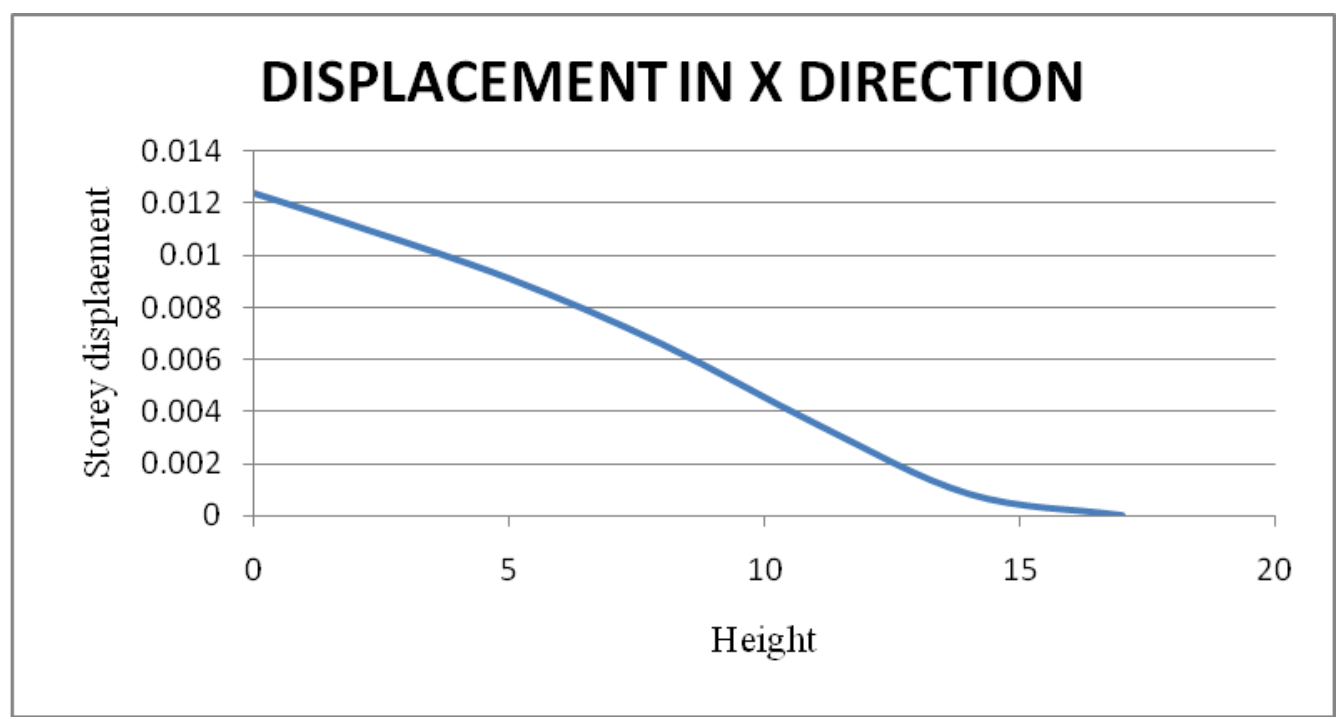

Fig no.10 Comparison of storey displacement for model1 


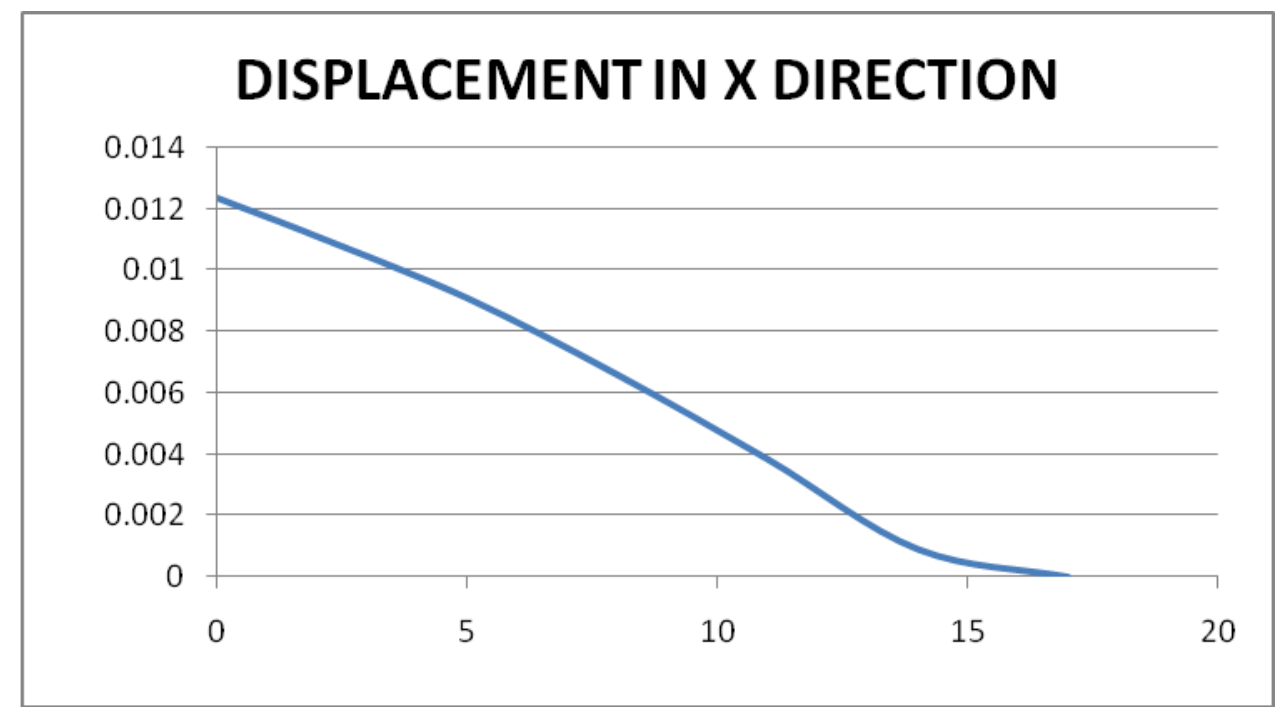

Fig no.11 Comparison of storey displacement for model2

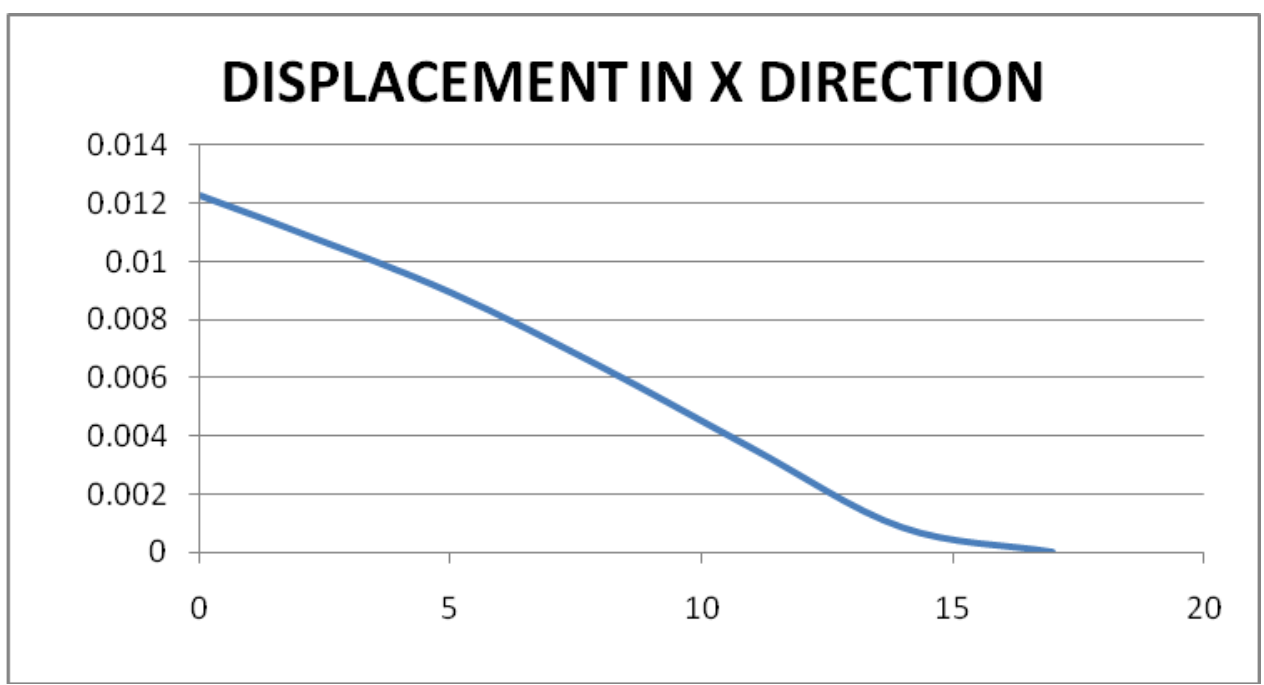

Fig no.12 Comparison of storey displacement for model3

\section{CONCLUSION}

Following are some of the conclusions which are drawn on the basis of this study. It was observed that in building as we introduce floating column at $1^{\text {st }}$ floor base shear of such building decreases as compared to building without floating column. also its was found that base shear increases from $1^{\text {st }}$ floor. It was observed that displacement of each storey of floating column building is more as compared to without floating column building.

\section{REFERENCES}

[1]. Sukumar Behera (may2012)-Seis mic analysis of multistory build ing with floating column, Department of Civil Engineering, National Institute of Technology Rourkela769008 MA Y 2012.

[2]. Shrikanth .M.K (2014)-Se is mic response of complex building with floating column and without floating column, International journal of Engineering Research-Online. A Peer Reviewed International Journal .Vol. 2., Is sue.4, 2014 .ISSN: 2321-7758

[3]. T.Raja. Sekhar (2014) - Study of behavior of seismic analysis of multistory building with and without floating column. T. Raja Sekhar et al, Carib .j. SciTech, 2014, Vol2, 697-710.

[4]. A. P. Mundada (2014) - Comparative seismic analysis of multi storey building with and without floating column ,International Journal of Current Engineering and Technology, Vol.4, No.5 (Oct 2014)

[5]. Hardik Bhensdadia(2015)- Pushover analys is of Rc structure with floating colu mn and soft storey in different earthquake zones , frame International Journal of Research in 
Engineering and Technology. Volume: 04 Is sue: 04 | Apr-2015.

[6]. Susanta Banerjee and Dr. Sanjaya K Patro(2014)-Estimation of park-Ang damage index for floating colu mn building with infill wall., 55th Annual Technical, Journal of Orissa State Centre, Institute of Engineers(India), 2014, pp.211-217.

[7]. Sreekanth Gandla Nanabala1(2014)Seis mic analysis of a normal building and floating column building, International Journal of Engineering Research \&technology.

[8]. Patyush Malaviya(2014) "Comparative study of effect of floating column on the cost analysis of a structure designed on staad pro v8i" International journal of scientific research and engineering research.

[9]. Shiwli roy Agarwal Pankaj, Shrikhande Manish (2009),Earthquake resistant design of structures PHI learning private limited, New Delhi.

[10]. Criteria for Earthquake Resistant design of structures,Part1: General provisions and buildings, IS 1893:2002, Bureau of Indian Standards, New Delhi.

[11]. IS 875 (Part-I) Bureau of Indian Standards (1987) Code of Practice for Design Loads (Other than Earthquake) for Buildings and Structures: Dead Loads-Unit Weights of Building Materials and Stored Materials (Second Revision). UDC 624.042: 006.76.

[12]. IS 875 (Part-II) Bureau of Indian Standards (1987) Code of Practice for Design Loads For Buildings and Structures: Imposed Loads (Second Revision). UDC 624.042.3:006.76.

[13]. Duggal S K (2010), "Earthquake Resistance Design of Structure", Four Edition, Oxford University Press, New Delhi.

[14]. SAP 2000v 17 package. 